\title{
COVID-19'S IMPACT ON THE HIGHER EDUCATION SYSTEM IN JORDAN: ADVANTAGES, CHALLENGES, AND SUGGESTIONS Ahmad S Haider $^{1^{*}}$, Saleh Al-Salman ${ }^{2}$ \\ ${ }^{1 *}, 2$ Applied Science Private University, Amman, Jordan. Email: ${ }^{1 *}$ ah_haider86@yahoo.com, ${ }^{2}$ salehalsalman2000@gmail.com
}

Article History: Received on $24^{\text {th }}$ July 2020, Revised on $15^{\text {th }}$ September 2020, Published on $28^{\text {th }}$ September 2020

\begin{abstract}
Purpose of the study: The present study surveys the reactions of university-level faculty members in Jordan towards their experience with COVID-19's emergency online learning model. It primarily investigates the advantages of switching to online learning, challenges faced, and suggestions for improving the teaching-learning process.
\end{abstract}

Methodology: The study is based on empirical data compiled from the responses of 432 instructors in six Jordanian public and private universities. The data collection instrument consists of a structured open-ended questionnaire, which comprises three constructs: challenges, advantages, and suggestions for improvement. Similar responses were combined in thematic categories and were calculated to obtain frequencies and percentages.

Main Findings: Concerning the advantages, e-learning enabled instructors to use new effective teaching tools and acquire new skills. The challenges were mainly related to technology and the Internet, assessment, interaction, and lack of clear vision and regulations by policymakers. Instructors suggested providing better technical support; blending online with traditional learning; offering more training, and improving the assessment tools and designing new ones.

Applications of this study: This study is useful for educational leaders and policymakers providing guidance and insights on how higher education institutions have responded to this global health emergency, and how they managed to meet the evolving needs of students and staff. Consequently, the higher education sector should be prepared to operate more efficiently and effectively for any future emergencies.

Novelty/Originality of this study: While different studies have investigated the impact of COVID-19 on the education sector globally, little attention has been given to developing countries in the Middle East. To this end, the present study focuses on how COVID-19 has been effective in reshaping and revolutionizing the higher education paradigm in Jordan through highlighting the advantages, challenges, and subsequent suggestions for improvement.

Keywords: COVID-19, Higher Education, E-learning, Jordan, Blended Learning, Instructors' Feedback.

\section{INTRODUCTION}

With COVID-19's surge as a contagious disease, so effective at spreading through communities reaching about 213 countries (Lu et al., 2020), many questions remain unanswered and concerns to be addressed regarding its short-term and long-term repercussions. The education system was among the hardest-hit sectors worldwide (Dhawan, 2020; Gurukkal, 2020; Johnson et al., 2020). The lockdown period accompanying the pandemic made it necessary for higher education institutions to keep their students engaged in the learning process. The impact of COVID-19 was overwhelming to affect global higher education, where international students have been directly involved. Consequently, some dramatic changes and regulatory measures have to be taken by stakeholders; i.e., higher education institutions and students alike. This may include a change of application deadlines, switching to distance-learning online courses, rescheduling start dates, changing plans, etc. Many higher education institutions worldwide are still uncertain about the possible reopening of schools in September 2020.

This intricate situation created by the COVID-19 outbreak calls upon researchers to address key questions in the higher education system pertaining to online learning (see Crawford et al., 2020; $\underline{\text { Haider \& Al-Salman, 2020; Wang et al., }}$ 2020). In this study, the research problem investigates how the COVID-19 crisis has affected the higher education system in Jordan. Its primary motivation is to reflect on the advantages gained, the challenges faced, and eventually provide suggestions for improving the quality of the online learning, which is most likely to continue in the postCOVID-19 era. The researchers believe that such contribution will bridge a gap in the status of the online learning being experimented in the Jordanian setting during the COVID-19 pandemic.

Amidst this row on the possible changes in the higher education sector, the question of transitioning and switching to distance and online learning topped the agenda. Linney (2020) believes that the higher education sector has witnessed dramatic changes as a result of the coronavirus, which requires immediate action for activating crisis management strategies. It is true that some higher education institutions have adopted distance learning for decades now but on a limited scale. Examples are found in the New England Institute of Technology, founded in 1940; The Open University (OU), established in 1969; and Athabasca University, Alberta, Canada, founded in 1970, among others. However, shifting permanently to an online teaching-learning model must be taken with the utmost vigilance and care. Schrager $(2020$, p. 2) reports that impacted by COVID-19, higher education institutions have opted for online learning. Such research findings leave a lot to be achieved and desired before we embark on a final decision switching to online learning. The number of institutions moving towards online learning is indeed increasing, but making final decisions 
should be based on empirical research findings which most succinctly depict students' and tutors' reactions, concerns, and challenges (Sheard \& Markham, 2005). The level of satisfaction with online courses depends on a variety of factors including course design and delivery of content, discipline, and time management (Alqurashi, 2019; Jaggars \& Xu, 2016; van Rooij \& Zirkle, 2016).

COVID-19's current situation has raised many questions about how the educational institutions have responded promptly to this state of emergency (Crawford et al., 2020; Johnson et al., 2020; Sahu, 2020). Given the above, and driven by the advent of COVID-19, the empirical nature of the present study seeks to address some fundamental aspects of online learning based on authentic first-hand reactions of one of the major stakeholders in the teaching-learning process, namely instructors.

The current study addresses the following questions:

1. What, according to instructors, advantages have been gained from the application of online learning in higher education institutions?

2. What are the substantial challenges encountered by instructors?

3. What are the most constructive suggestions offered by instructors in this context?

\section{LITERATURE REVIEW}

Lately, technology has interfered with the firmly-established college education experience. Modes, techniques, and strategies of education have been remodelled to cope with the rapid and substantial changes in science and technology. Distance learning and e-learning have been thriving in the information and communication age driven by advances in science and technology. Internet and telecommunication companies are introducing new technologies at a highly accelerated rate (Al-Azawei et al., 2017; Dominici \& Palumbo, 2013; Englund et al., 2017; Santos et al., 2019). The sweeping trend fueled by the powerful arm of technology reached out to impact all facets of life. The presence of the Internet in our lives has been so evolutionary to change education, business, social life, and a world without barriers to knowledge, communication, and interaction (Silva \& Cartwright, 2017). According to Gurukkal (2020, p. 1), the devastating COVID-19 will have grave economic and social consequences, with higher education being featured, "turning the world into another techno-economic culture". This required taking immediate action by devising a crisis response and a proactive crisis management plan to avoid disrupting the normal teaching-learning process.

According to Schrager (2020), COVID-19 is reshaping the way we view higher education, which may be customized to institutions' and learners' needs. In this case, a multimodal and hybrid teaching-learning model may be preferred (Siripongdee et al., 2020). For example, regarding students' interaction with professors, larger classes may be better served through online learning. In comparison, smaller classes and seminars may be taught face-to-face where instructors can discipline, monitor, and guide students through their work. In other words, technology can make a difference whereby education models can be more flexible and more responsive to students' needs, especially in the postCOVID-19 era. Such potential changes to traditional on-ground education will most likely lead to adjustments in the financial bill of higher education consumers and universities for some of which education is the business (Wang et al., 2020). Consequently, it is imperative to seek first-hand reactions and feedback from key players in the teaching-learning process, faculty members, and students, which the present study is investigating.

Research on faculty members' views, reactions, and attitudes towards the e-learning practice and the roles of e-learning instructors in higher education has been the subject of a study by Chang et al. (2014, p. 72). Their analytical results indicate that "content expertise" and "instructional designer" are perceived by university faculty as the key components in e-instruction in higher education". At the same time, the study calls for e-instructor training. Dhawan $(2020$, p. 2$)$ reports that "although many academic units have shifted to blended learning in India, some still follow the traditional face-to-face model. But with the advent of the COVID-19 pandemic, many academic institutions that were earlier reluctant to change their traditional pedagogical approach had no option but to shift entirely to online teaching-learning".

Upon surveying students' reactions on the advantages of online learning, Roach and Lemasters (2006) report that once students are not experiencing face-to-face classroom instruction, they will start using additional resources and become their own investigators, learning and discovering more about their capabilities as independent learners. Comparisons between face-to-face instruction and online learning are usually based on course design and structure, presentation and delivery of subject matter, and completion rate (Nemetz et al., 2017; Soffer \& Nachmias, 2018). In the same vein, Isaeva et al. (2020, p. 1) report that the COVID-19 lockdown period "has pushed instructors to use this opportunity to excel in their techno-pedagogical skills. They now are quickly progressing with newly acquired digital competence".

On the question of reshaping learning, one of the main disadvantages of COVID-19 is the absence of social interaction in the educational process, resulting in social isolation. O'Sullivan et al. (2017) argue that, from a social learning theory perspective, socialization --which is exercised in face-to-face learning-- is a fundamental element for cognition and understanding. However, this depends on the instructors' skills and guidance on how to implement multi-modality in the educational process, through a combination of technology that is conducive to stimulation and interaction (Cigognini et al., 2011). Concerning the importance of student engagement in online learning, Isayeva (2020) argues that universities 
are currently required to provide faculty members who are competent enough in student-engagement activities and communication.

Although online learning will not replace traditional face-to-face delivery, universities must be prepared for the new reality (Njenga \& Fourie, 2010; Tamim, 2018; Zhang \& Zhou, 2003). It is noteworthy, however, that any future shift which might be triggered and accelerated by the COVID-19 pandemic should take into consideration the student-faculty interaction and peer interaction. Timely and regular communication with instructors for guidance, directions, course requirements, modes and tools of delivery, and assessment methods are vital factors in fostering students' satisfaction (Alqurashi, 2019; Jaggars \& Xu, 2016; van Rooij \& Zirkle, 2016). Because of the above, this study deemed it essential for e-instructors to have relevant experience in designing the right content for e-learning classes. The design of an online course should include the instructional, media, evaluation, and delivery strategies. Including these elements in the course content will facilitate students' participation in a virtual teaching environment (Almaiah \& Alyoussef, 2019; Martin et al., 2019).

Johnson et al. (2020, p. 1) argue that COVID1-19 had affected higher education around the world rapidly and profoundly, leading to a quick transition to emergency remote teaching. As a result, faculty members without prior experience in online teaching had no choice but to receive the necessary training and adapt to the new teaching-learning model.

The impact of the COVID-19 pandemic on higher education around the world was the subject of different studies (Dhawan, 2020; Gurukkal, 2020; Johnson et al., 2020). Marinoni et al. (2020, p. 6) report that "one particular issue that the COVID-19 pandemic has shown is the need for increased international and global perspectives to analyze the various impacts of COVID-19 in the short-medium and long term". The authors add that there is an urgent need to rethink the future of higher education at different levels where policymakers, public and private sectors, and international organizations need to work together in a collaborative environment. Closing schools and Higher Education Institutions (HEIs) in 213 countries should not go unnoticed when campus activities were stopped, and education was disrupted.

\section{METHODOLOGY}

The data for this study is derived from the responses of 432 instructors. Faculty members, representing three public and three private universities that are based in Jordan, were asked to fill in an electronic questionnaire that was sent to their personal and institutional emails. The snowball technique was used as instructors were requested to forward the questionnaire link to colleagues in the same institutions. The 432 instructors' sample included 224 female faculty members (52\% of the sample) and 208 male instructors (48\% of the sample) who were affiliated with different universities in the Humanities and the Sciences.

\section{Research Instrument}

The researchers developed a structured questionnaire that was launched on the Microsoft Forms platform. The questionnaire has open-ended questions to elicit faculty members' responses with respect to their feedback on how their higher education institutions have responded to this global health emergency, and how they managed to meet the evolving needs of students and staff. The research findings can be utilized at two levels; first, evaluating the online learning experience in conjunction with the three variables (advantages, challenges, and suggestions for improvement). Second, how to help the higher education sector function more efficiently and effectively having been impacted by the COVID-19 crisis.

The questionnaire consisted of two main sections. The first section aimed to collect demographic data on gender, specialization, and affiliation. The second section consisted of three open-ended questions, as follows:

- Please list the advantages of e-learning compared to face-to-face learning.

- Please list the challenges you have faced throughout the e-learning experience.

- Please list as many suggestions, you deem necessary, for improving the online learning practice.

In this section, instructors were asked to list as many points as they can, ordering them from the most significant to the least significant. Each point is considered a response. For example, if an instructor mentions five advantages, they will be counted as five different responses. Similar responses were combined in thematic categories based on the general theme they discussed. For example, Internet issues, technical problems, and platform issues were combined under the thematic group of 'Technical and Internet Problems'. The data from the questionnaire were calculated to obtain frequencies and percentages.

\section{FINDINGS AND DISCUSSION}

The results are presented under three main subheadings, namely, advantages, challenges, and suggestions.

\section{Advantages}

This section discusses the instructors' responses about the advantages of e-learning compared to face-to-face learning. 
The responses of the instructors on the statement of 'please list the advantages of e-learning compared to face-to-face learning' were divided into four main categories, namely new effective teaching tools (33\%); acquiring new skills (26\%); a quick and practical solution for emergencies (24\%), and flexibility in time and communication (17\%), as Figure 1 shows.

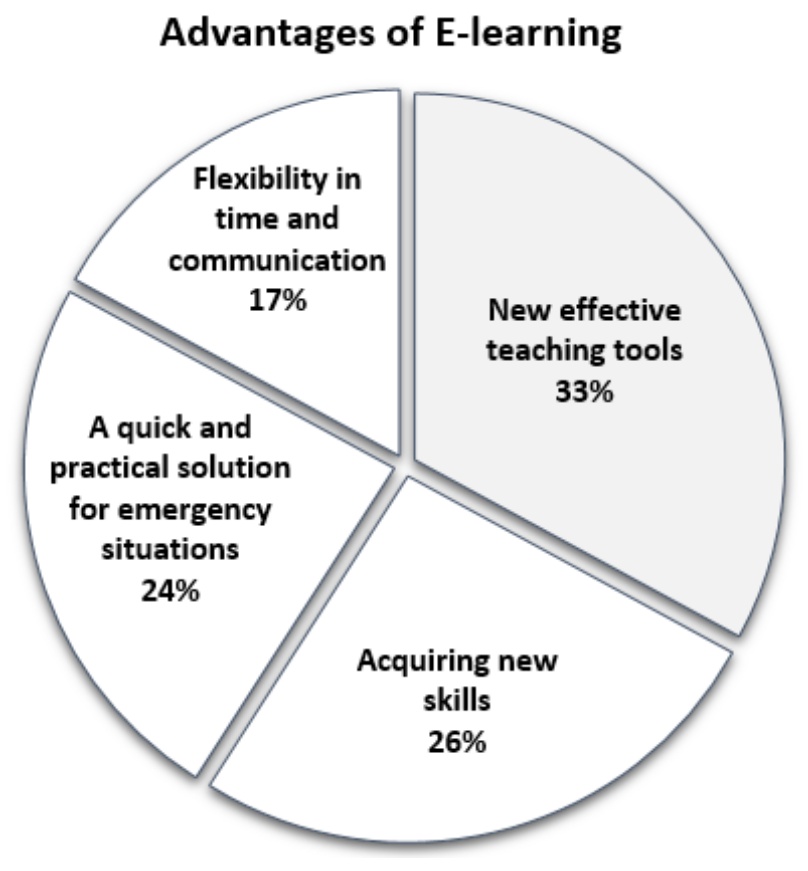

Figure 1: Advantages of e-learning from instructors' perspectives

- New effective teaching tools

According to some instructors, using the platforms, students can present their digital work efficiently and promptly. Instructors also stated that e-learning motivated them to prepare multimedia files for the different courses. Multimedia can create a stimulating, motivating, and interactive teaching-learning environment for both faculty and students. Research has shown that the effectiveness of online learning depends largely on providing state-of-the-art and cuttingedge teaching-learning tools, which will boost instructors' performance and delivery (Roach \& Lemasters, 2006). Design of content, use of audio-visual tools for interaction, and content delivery are keys to securing students' satisfaction and recruitment (Cheng \& Chau, 2016; Chigeza \& Halbert, 2014; Martín-Rodríguez et al., 2015). With students' satisfaction being a top priority, securing practical teaching tools will contribute significantly to students' satisfaction.

Further, instructors reported that recording the lecturers encourages them to give the best of what they have as the lectures will be permanently made available for students, and enables them to review their performance later. This ties nicely with the thesis that online-learning is here to stay, and that COVID-19 has been the driving force behind accelerating the process. For the shift to online learning to be functional, Institutions should be prepared to invest more in the technical infrastructure, learning management systems, and cloud services to have easy access to digital education resources (Marinoni et al., 2020). The fact that the sample members participating in this study have voted (33\%) for the category of 'new effective teaching tools' is consistent with the emphasis put on this very point in the online learning literature.

- E-learning is useful for acquiring new skills

From an instructors' perspective, online learning tools are useful for both instructors and students to acquire new skills such as creativity, critical thinking, and problem-solving. E-learning helps students be more independent and have better time management. It also helped a good number of them gain more confidence in expressing themselves and being more interactive, a property which they lacked in face-to-face meetings. It also assists students and instructors in developing some new technical skills. According to Cigognini et al. (2011), well-trained instructors are capable of creating an elearning environment where, through guidance, motivation, and encouragement students can utilize technology as a means of informal learning. This enables, even less motivated students to be more engaged, confident, and selfdependent (Isaeva et al., 2020). With $26 \%$ of the faculty members' sample focusing on 'acquiring new skills', the findings of the present study confirm with the value attributed to online learning as a mechanism for empowering learners with new technical, intellectual, and personal development skills (Bolliger \& Martin, 2018).

- E-learning is a quick and practical solution for emergency situations 
E-learning has been a new experience for instructors and students alike. For many instructors, it is is a good step in the right direction towards integration and coping with the innovations in science and technology. One of the responses was 'the future is heading towards the online learning, and this was a great opportunity to be part of this experience'. Instructors also stated that online learning should be used alongside the traditional face-to-face teaching method in the future. However, it is also argued that the online model suits specific modules and courses but not all. In support of this thesis, the authors believe that no better example to prove the value of e-learning in offering practical solutions for emergencies than the sudden and stealthy outbreak of COVID-19. Marinoni et al. (2020, p. 26) argue that "this unplanned and unprepared experiment in distance teaching and learning has led to capacity building of staff and faculty who have learned and tested new tools and systems to enable distance teaching and learning".

- Flexibility in time and communication

According to the instructors, e-learning saves some time for them to conduct other activities like research. E-learning also enables students to communicate with their instructors and colleagues via different means, including text messages, emails, chat rooms, and phone calls. Instructors also believe that e-learning saves time, especially when dealing with courses of theoretical nature. Instructors and students alike find a breathing room in e-learning as it is not a time-bound activity (Ortega-Morán et al., 2020; Sun et al., 2008). This feature of flexibility in learning lends support to the voices calling for expanding the realm of online schooling where one can plan, prioritize, and program.

\section{Challenges}

This section aims to collect feedback about the instructors' perception of the online learning systems compared to the onsite classrooms by listing the challenges they have faced throughout the e-learning experience.

The instructors' responses on the question 'please list the challenges you have faced throughout the e-learning experience' were categorized as follows: technical and Internet problems (33\%); course-related issues and workload (23\%); insufficient tools for student assessment (17\%); student commitment, awareness, and psychology (15\%); and lack of clear vision and regulations by decision/policymakers (12\%), as Figure 2 shows.

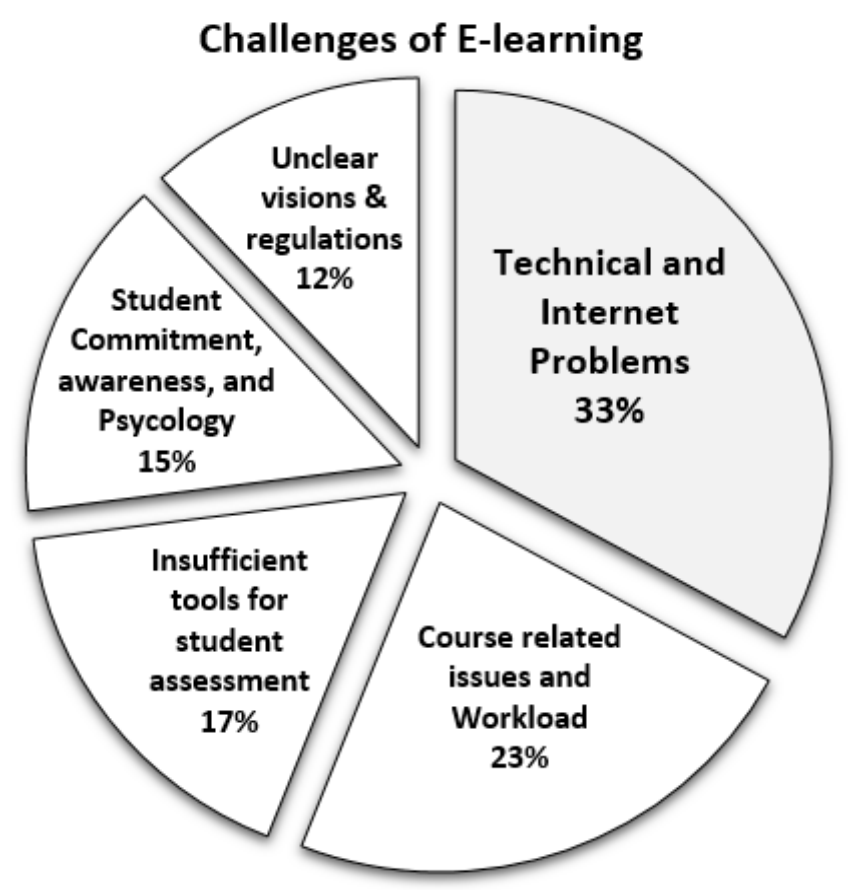

Figure 2: Challenges of e-learning from teachers' perspectives

- Technical and Internet problems

Internet problems were the main challenge that the instructors raised; these included poor connection and slow Internet speed. They argued that there is a lack of necessary and essential electronic equipment, where not all of the students, and sometimes instructors, have good personal computers or laptops. Instructors also stated that they faced some technical problems, especially in the first days of applying the novel teaching experience. For example, they did not have full control and management over their classes.

Instructors also argued that some of them had limited technical experience (Rasheed et al., 2020). The same applies to some students, whose computer and Internet literacy and technical skills are limited. Marinoni et al. (2020) report that Higher Education Institutions' (HEIs) sustainability of online learning is corollary with the availability of technical support. The two-thirds of the HEIs in the world which were able to move to online education were better equipped and 
more technically advanced than the third that was unable to do so. The modality of using digital resources such as tablets, smartphones, and Internet-linked devices has become so essential in modern-day education systems. Lack of technically-advanced e-learning tools poses a challenge to instructors, students, and the institutions' aspirations to join the ranks of advanced e-learning centres, where flipped classrooms, mobile learning, blended learning, and microlearning modalities are implemented.

- Course-related issues and workload

A good number of instructors argued that it is difficult to explain all materials, especially the practical ones. One of the responses was "some courses, in Art and Design, do not apply to e-learning, and these are based on real studio environment". Sometimes, the e-learning environment makes it difficult to pass the information to the students in the right way. Another response was "since my courses for this semester are practical ones, I believe that face-to-face interaction with the students is a must". Some instructors said that they faced difficulties in demonstrating and explaining specific topics. For example, one of the responses was "we faced so many problems teaching architectural design online; we did everything we can (using programs and simulations, among others). It's a practical course, and you need to be face-to-face with the students most of the time to sketch with them, do models with them, analyze the site with them, and so on". Similarly, it was difficult for instructors to teach courses that have labs. For example, an instructor said: "teaching labs is not efficient without the students learning how to do the experiment and how to interpret and discuss the results". Subscribing to this thesis, Cadloff $(2020$, p. 2) argues that "there are courses that simply do not translate easily to an online substitute".

Some instructors said that they exert tremendous efforts to finish the preparations needed to conduct an online course efficiently and effectively. Others said that they needed to spend extended times using their laptops and computers without moving, and this put more pressure on them. In this context, Kebritchi et al. (2017, p. 1) report that in the process of transitioning to the online system, instructors face additional challenges where they need to change their roles, taking into consideration content development, teaching styles, and time management, which add to their workload. As such, higher education institutions are required to provide more technical support and professional development for the faculty members.

Preparing, planning, and designing the materials for the e-learning environment posed a challenge to most instructors, bearing in mind that the current novel teaching experience forced by COVID-19 was the first for most of them. As they put it, they needed to grab the attention of the students without distraction. The same was expressed by Cadloff (2020), stating that the act of engaging students poses a significant challenge to faculty members entering the online experience for the first time. According to Baran et al. (2011), teachers are expected to take new roles by adopting more dynamic and facilitative approaches compatible with online instruction.

- Insufficient tools for student assessment

Some instructors argued that online assessment methods are not as efficient as those in face-to-face teaching, particularly quizzes and exams; they do not reflect the actual knowledge or skills of students. Faculty members complained about the noticeably high cheating rate, where students' grades in the virtual learning environment were significantly higher than their results in the previous semesters, which were based on the on-ground education. It was also argued that the online evaluation does not suit the nature of some courses. One of the responses read, "many courses in the Architect Engineering need direct rubbing shoulders with students, and the performance of enrolled students in these courses cannot be easily assessed". According to Marinoni et al. (2020, p. 25), some fields of study have their limitations in the online domain. These include "clinical medicine, veterinarian studies, and several disciplines depending on access to laboratories. The same applies to many other creative disciplines such as arts, music, and design". Since some courses do not translate easily into online substitutes (Burke, 2020), then these courses will be hard to assess remotely.

- Student commitment, awareness, and psychology

A good number of instructors considered the absence of face-to-face interaction with students a disadvantage. Some students do not have a high degree of commitment and seriousness to fully integrate and adapt to the e-learning mode (Morgan-Thomas \& Dudau, 2019). In e-learning, students, according to some instructors, are less interactive than in traditional education, and their responses and feedback are inadequate. Some students are not fully prepared for elearning, and their perception of the concept of distance/e-learning is unclear. Schrager (2020, p. 2) argues that "remote schooling has not been an unmitigated success, at least so far".

- Lack of clear visions and regulations

Some of the instructors had concerns about having regulations and bylaws that organize the process, bearing in mind that it is the first online experience for most of them. A good number of them argued that most university administrations do not have clear procedures and instructions for conducting and implementing the e-learning experiment, and these include attendance, assessment methods, and sending lots of memorandums and decisions on a daily basis. One of the responses was "there are not enough rules and regulations to control students' attitudes and behaviours during e-learning". The researchers believe that faculty and students should be enlightened about the rules and regulations which govern distance 
and online education. According to $\underline{S t}$ Phard Jr (2015, p. 15), "a university needs to offer distance education in order for it to remain competitive and innovative. For this to happen, it is important to discuss and bridge the perception gap between university administration and faculty with regard to concern and policies".

\section{Suggestions}

This section discusses the instructors' responses and suggestions towards boosting the online learning experiment.

Instructors' responses to the question of "please list as many suggestions, you deem necessary, for improving the online learning" were categorized as: providing better technical support (32\%); blending online with traditional learning (25\%); more training courses and psychosocial support(18\%); improving assessment tools and designing new ones (13\%), and having clear regulations and bylaws (12\%), as Figure 3 shows.

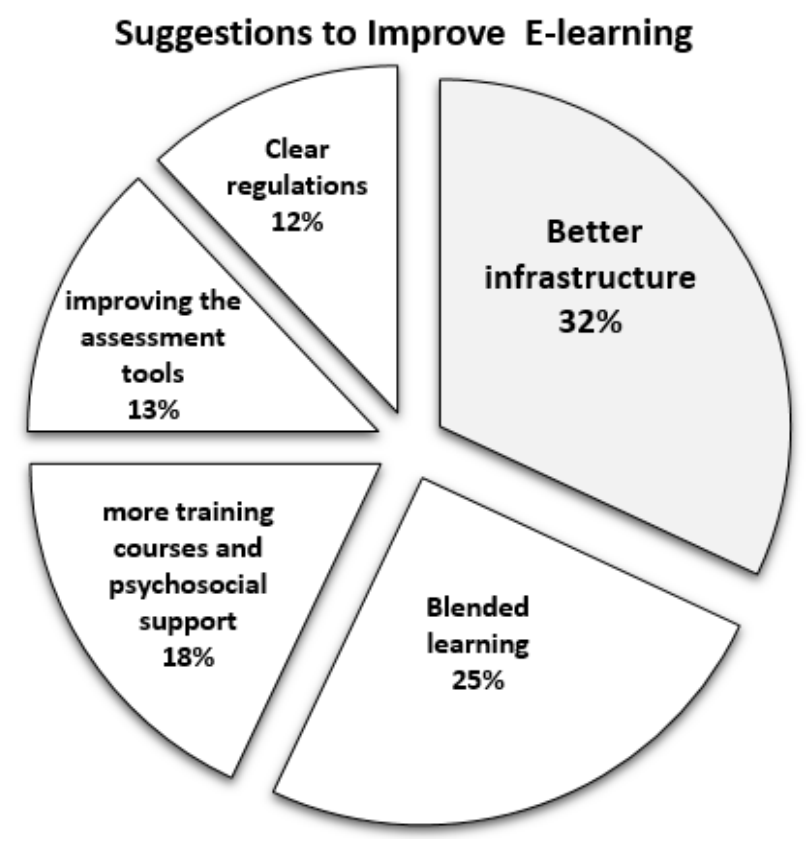

Figure 3: Suggestions to improve the e-learning from teachers' perspectives

- Providing better technical support

A good number of the instructors recommended that Jordan, as a country, and universities, being institutions of Higher Education, should improve the technical infrastructure. They suggested that the Internet should be free or at least be provided by universities. Instructors also stated that, for e-learning to be more successful, it is necessary to make sure that all students have the most up-to-date tools (computers or laptops), and have good Internet connections. They stressed that more technical support for the instructors and students is needed. They proposed designing new technologies, platforms, and tools that suit the new phase of learning and ensure a more interactive environment with students. The topical importance of technology was heavily emphasized in the literature on e-learning. The above findings on the role of 'technology use and skills' in supporting online learning are in line with the results of different research studies. For example, Carlson (2005) argues that the shift to distance-learning supported by digital e-learning technology is compatible with the new generation of college students who crave further applications of the technological advances in the classroom. Ryan et al. (2010) believe that e-instructors are required to cope and be abreast of the complex nature of the e-learning tools.

- Blending online with traditional learning

As a transitional stage, some instructors recommended blending the virtual learning model with on-ground education, making it part of the learning process. One of the responses reads, "face-to-face education should include one or two electures per week to increase experience in the e-learning field for both students and tutors". They also proposed that all instructors should teach an e-learning course a semester to get used to it. However, they emphasized that e-learning is suitable for a limited number of courses primarily in the Humanities disciplines, and may be applied for only $25 \%$ of the course offered by the Science disciplines as they need face-to-face applications. In this context, Marinoni et al. (2020) and Cadloff (2020) argue that some courses, especially in the sciences, medicine, and technology, together with some others in the arts disciplines do not feature a typical fit for online classes. On the other hand, the need for adopting a blended learning model was addressed by Barquero (2020, p. 1) who stressed the importance of combining online training with the face-to-face one. 
- More training courses and psychosocial support are needed

Instructors suggested that better preparations of students and instructors for the concept of distance learning, importance, and values should be taken seriously. Psychosocial support for students is a necessity to be receptive to the notion of elearning and be willing to adapt. Similarly, students' and instructors' awareness of technology should be raised. Instructors also stated that there should be more training courses on using e-learning for both faculty members and students. One of the responses called for the "proper training of instructors and students on how to use the e-learning software". E-instructors are expected to acquire the necessary technical skills so that they can integrate technology in cooperative teaching-learning strategies (Alariqi et al., 2019).

Improving the assessment tools and designing new ones

Since students' assessment was one of the significant challenges, instructors recommended finding an effective way to evaluate students' performance. Accordingly, improving exam software to secure efficient and fair testing is a necessity. One of the responses was "securing trusted evaluation methods like quizzes and exams is a must". Instructors are required to be more creative and design their course content to suit the assessment method of the e-learning mode. Chang et al. (2014, p. 72) list assessment and evaluation among the benchmarks, which are considered essential to ensure excellence in online instruction. According to Burns (2018, p. 1), assessment is typically the weakest component of an e-learning program, which --if not implemented effectively--may impede rather than enable learning.

- Organizing the process and having clear regulations and bylaws

Some instructors suggested that the e-learning process should be more organized and regulations and bylaws systemizing the process should be more explicit and well-defined. As they put it, instructors should have at their disposal materials and equipment for a successful explanation and delivery of materials of practical nature. In this context, they suggested enacting a group of regulations concerning e-learning and giving workshops for students about the ethical issues related to e-learning.

\section{CONCLUSION}

The present study has most conspicuously identified the crucial role of Information and Computer Technology (ICT) in education, especially with the advent of the COVID-19 pandemic. More than ever before, the current crisis has alerted educational institutions, education specialists, and policymakers that online learning is here to stay and will most likely be implemented on a large scale. Institutions are, therefore advised to invest in developing the technical and digital competence of the teaching staff (Isaeva et al., 2020). This has proved to be extremely important in the aftermath of the sudden and unprepared shift to online teaching. Pedagogically and academically speaking, education centres hastened to respond to the COVID-19 call by providing all necessary means to continue the teaching-leaning process.

The current research findings on the role of COVID-19 in revolutionizing the higher education system came to support the growing trend towards expanding online learning strongly. The three key constructs of the study, namely, advantages of online learning, challenges, and suggestions for improvement, were investigated from the instructors' perspectives. Instructors valued the online learning role in introducing new effective teaching tools, acquiring new skills, providing quick and practical solutions for emerging situations, flexibility in time and communication, as well as saving time and effort. On the level of challenges faced, instructors underscored the importance of resolving ICT technical and Internet problems as they make or break the online learning practice. Similarly, compatibility of course design and content with the online learning tools was considered a significant challenge and an area of concern. Besides, students' evaluation and assessment tools must be re-considered to suit the new learning model. For instructors, students' commitment and awareness of the virtual learning environment setup posed a challenge. As for the suggestions package, instructors called for the provision of more advanced infrastructure and technical support, developing and expanding the principle of blended learning, extra emphasis on training courses, and devising and improving assessment tools.

To conclude, the research findings, based on the three research questions posed earlier, are supportive of digitalizing higher education. Distance and online learning competencies and pedagogies should be emphasized. However, institutions should be prepared to invest more in providing a highly sophisticated technical infrastructure to allow for a shift in this direction. Furthermore, it is quite important to change the mindset of the small percentage of instructors and students who may have some reservations against the new experiment so that they can gradually accept the online model as an integral part of the education system.

\section{LIMITATION AND STUDY FORWARD}

This study has some limitations as it investigates the impact of COVID-19 on a particular academic level, namely tertiary education, from the instructors' perspective, within a defined timeframe (post COVID-19 era), and geographical context (Jordan) to answer three research questions. Consequently, further research will be necessary to examine the impact of switching to the e-learning model in the COVID-19 context with special emphasis on secondary education. Given that this study focused on the instructors' feedback as one of the major stakeholders of the educational process, additional research attempts will be needed to tackle similar issues from the students' perspective. That the current study focuses on the period that immediately followed the outbreak of the COVID-19 pandemic, it is recommended that other 
researchers examine the long-term repercussions of shifting to the e-learning paradigm. Finally, as this study explores the impact of COVID-19 on the higher education institutions in Jordan, it is recommended that other researchers conduct similar research on how other countries have responded to this emergency situation.

\section{ACKNOWLEDGEMENT}

The researchers would like to thank the instructors who participated in the survey.

\section{AUTHORS CONTRIBUTION}

Conception or design of the work: First + Second Authors.

Data collection: First Author.

Data analysis: First Author.

Data interpretation: Second Author.

Drafting the article: Second Author.

Critical revision of the article: First + Second Authors.

Final approval of the version to be published: Second Author.

\section{REFERENCES}

1. Al-Azawei, A., Parslow, P., \& Lundqvist, K. (2017). Investigating the effect of learning styles in a blended elearning system: An extension of the technology acceptance model (TAM). Australasian Journal of Educational Technology, 33(2), 1-23. https://doi.org/https://doi.org/10.14742/ajet.2758

2. Alariqi, A. A., Najafi, M., Abdulrab, M., Murray, C., \& Slimanzai, H. (2019). Factors Affecting E-Learning Effectiveness in a Higher Learning Institution in Afghanistan. Proceedings of the 2019 11th International Conference on Education Technology and Computers,

3. Almaiah, M. A., \& Alyoussef, I. Y. (2019). Analysis of the effect of course design, course content support, course assessment and instructor characteristics on the actual use of E-learning system. IEEE Access, 7, 171907-171922. https://doi.org/10.1109/ACCESS.2019.2956349

4. Alqurashi, E. (2019). Predicting student satisfaction and perceived learning within online learning $\begin{array}{llll}\text { environments. } & \text { Distance } & \text { Education, } & \text { 133-148. }\end{array}$ https://doi.org/https://doi.org/10.1080/01587919.2018.1553562

5. Baran, E., Correia, A.-P., \& Thompson, A. (2011). Transforming online teaching practice: Critical analysis of the literature on the roles and competencies of online teachers. Distance Education, 32(3), 421-439. https://doi.org/https://doi.org/10.1080/01587919.2011.610293

6. Barquero, J. (2020). Main e-learning modalities. Innovative Learning Solutions. Innovative Learning Solutions. https://www.cae.net/e-learning-modalities/

7. Bolliger, D. U., \& Martin, F. (2018). Instructor and student perceptions of online student engagement strategies. Distance Education, 39(4), 568-583.

8. Burke, K. (2020). "How can the creative arts possibly be taught online?" Perspectives and experiences of online educators in Australian higher education. Asia-Pacific Journal of Teacher Education, 1-15. https://doi.org/https://doi.org/10.1080/1359866X.2020.1777531

9. Burns, M. (2018). Improving assessment in eLearning Programs. E-learning Industry https://elearningindustry.com/assessment-in-elearning-programs-improving

10. Cadloff, E. (2020). The big transition begins as faculty switch to online learning in response to COVID-19. University Affairs. https://www.universityaffairs.ca/news/news-article/the-big-experiment-begins-as-facultyswitch-to-online-learning-in-response-to-covid-19/

11. Carlson, S. (2005). The net generation goes to college. The chronicle of higher education, 52(7), A34.

12. Chang, C., Shen, H.-Y., \& Liu, E. Z.-F. (2014). University faculty's perspectives on the roles of e-instructors and their online instruction practice. International Review of Research in Open Distributed Learning, 15(3), 7292. https://doi.org/https://doi.org/10.19173/irrodl.v15i3.1654

13. Cheng, G., \& Chau, J. (2016). Exploring the relationships between learning styles, online participation, learning achievement and course satisfaction: An empirical study of a blended learning course. British journal of educational technology, 47(2), 257-278. https://doi.org/ https://doi.org/10.1111/bjet.12243

14. Chigeza, P., \& Halbert, K. (2014). Navigating E-Learning and Blended Learning for Pre-Service Teachers: Redesigning for Engagement, Access and Efficiency. Australian Journal of Teacher Education, 39(11), 133146. https://doi.org/http://dx.doi.org/10.14221/ajte.2014v39n11.8 ( )

15. Cigognini, M. E., Pettenati, M. C., \& Edirisingha, P. (2011). Personal knowledge management skills in Web 2.0-based learning. In M. J. Lee, and Catherine McLoughlin (Ed.), Web 2.0-based e-learning: Applying social informatics for tertiary teaching (pp. 109-127). Information Science Reference. 
16. Crawford, J., Butler-Henderson, K., Rudolph, J., \& Glowatz, M. (2020). COVID-19: 20 Countries' Higher Education Intra-Period Digital Pedagogy Responses. Journal of Applied Teaching Learning, 3(1), 1-20. https://doi.org/ https://doi.org/10.37074/jalt.2020.3.1.7

17. Dhawan, S. (2020). Online Learning: A Panacea in the Time of COVID-19 Crisis. Journal of Educational Technology Systems, 1-18. https://doi.org/https://doi.org/10.1177/0047239520934018

18. Dominici, G., \& Palumbo, F. (2013). How to build an e-learning product: Factors for student/customer satisfaction. Business Horizons, 56(1), 87-96. https://doi.org/https://doi.org/10.1016/j.bushor.2012.09.011

19. Englund, C., Olofsson, A. D., \& Price, L. (2017). Teaching with technology in higher education: understanding conceptual change and development in practice. Higher Education Research Development, 36(1), 73-87. https://doi.org/ https://doi.org/10.1080/07294360.2016.1171300

20. Gurukkal, R. (2020). Will COVID 19 Turn Higher Education into Another Mode? Higher Education for the Future, 1-8. https://doi.org/10.1177/2347631120931606

21. Haider, A. S., \& Al-Salman, S. (2020). Dataset of Jordanian University Students' Psychological Health Impacted by Using E-learning Tools during COVID-19. Data in Brief, 32. https://doi.org/https://doi.org/10.1016/j.dib.2020.106104

22. Isaeva, R., Eisenschmidt, E., Vanari, K., \& Kumpas-Lenk, K. (2020). Students' views on dialogue: improving student engagement in the quality assurance process. Quality in Higher Education, 26(1), 80-97. https://doi.org/https://doi.org/10.1080/13538322.2020.1729307

23. Isayeva, R. (2020). How Covid-19 is reshaping teaching and learning: A perspective from Khazar University. SPHERE Consortium: Support and Promotion for Higher Education Reform Experts. https://supporthere.org/news/how-covid-19-reshaping-teaching-and

24. Jaggars, S. S., \& Xu, D. (2016). How do online course design features influence student performance? Computers Education, 95, 270-284. https://doi.org/https://doi.org/10.1016/j.compedu.2016.01.014

25. Johnson, N., Veletsianos, G., \& Seaman, J. (2020). US Faculty and Administrators' Experiences and Approaches in the Early Weeks of the COVID-19 Pandemic. Online Learning, 24(2), 6-21. https://doi.org/http://dx.doi.org/10.24059/olj.v24i2.2285

26. Kebritchi, M., Lipschuetz, A., \& Santiague, L. (2017). Issues and challenges for teaching successful online courses in higher education: A literature review. Journal of Educational Technology Systems, 46(1), 4-29. https://doi.org/https://doi.org/10.1177/0047239516661713

27. Linney, S. (2020). How is COVID-19 Shaping the Higher Education Sector? QS. https://www.qs.com/how-iscovid-19-shaping-the-higher-education-sector/

28. Lu, N., Cheng, K.-W., Qamar, N., Huang, K.-C., \& Johnson, J. A. (2020). Weathering COVID-19 storm: Successful control measures of five Asian countries. American Journal of Infection Control, 48(7), 851-852. https://doi.org/10.1016/j.ajic.2020.04.021

29. Marinoni, G., Land, H. v. t., \& Jensen, T. (2020). The Impact of Covid-19 on Higher Education around the World. https://www.iau-aiu.net/IMG/pdf/iau_covid19 and he survey report final may 2020.pdf

30. Martín-Rodríguez, Ó., Fernández-Molina, J. C., Montero-Alonso, M. Á., \& González-Gómez, F. (2015). The main components of satisfaction with e-learning. Technology, Pedagogy Education, 24(2), 267-277. https://doi.org/https://doi.org/10.1080/1475939X.2014.888370

31. Martin, F., Ritzhaupt, A., Kumar, S., \& Budhrani, K. (2019). Award-winning faculty online teaching practices: Course design, assessment and evaluation, and facilitation. The Internet Higher Education, 42, 34-43. https://doi.org/https://doi.org/10.1016/j.iheduc.2019.04.001

32. Morgan-Thomas, A., \& Dudau, A. (2019). Of Possums, Hogs, and Horses: Capturing the Duality of Student Engagement in eLearning. Academy of Management Learning Education, 18(4), 564-580. https://doi.org/https://doi.org/10.5465/amle.2018.0029

33. Nemetz, P. L., Eager, W. M., \& Limpaphayom, W. (2017). Comparative effectiveness and student choice for $\begin{array}{llll}\text { online and } \quad \text { face-to-face } & \text { classwork. }\end{array}$ https://doi.org/https://doi.org/10.1080/08832323.2017.1331990

34. Njenga, J. K., \& Fourie, L. C. H. (2010). The myths about e-learning in higher education. British journal of educational technology, 41(2), 199-212. https://doi.org/https://doi.org/10.1111/j.1467-8535.2008.00910.x

35. O'Sullivan, D., Krewer, F., \& Frankl, G. (2017). Technology enhanced collaborative learning using a projectbased learning management system. International Journal of Technology Enhanced Learning, 9(1), 14-36. https://doi.org/10.1504/IJTEL.2017.084085

36. Ortega-Morán, J.-F., Pagador, B., Maestre-Antequera, J., Arco, A., Monteiro, F., \& Sánchez-Margallo, F. M. (2020). Validation of the online theoretical module of a minimally invasive surgery blended learning course for nurses: A quantitative research study. Nurse education today, 89, 1-9. https://doi.org/https://doi.org/10.1016/j.nedt.2020.104406

37. Rasheed, R. A., Kamsin, A., \& Abdullah, N. A. (2020). Challenges in the online component of blended learning: A systematic review. Computers Education, 144, 103701. https://doi.org/https://doi.org/10.1016/j.compedu.2019.103701

38. Roach, V., \& Lemasters, L. (2006). Satisfaction with online learning: A comparative descriptive study. Journal of Interactive Online Learning, 5(3), 317-332. 
39. Ryan, J., Scott, A., \& Walsh, M. (2010). Pedagogy in the multimodal classroom: An analysis of the challenges and opportunities for teachers. Teachers Teaching: theory practice, 16(4), 477-489. https://doi.org/https://doi.org/10.1080/13540601003754871

40. Sahu, P. (2020). Closure of universities due to Coronavirus Disease 2019 (COVID-19): impact on education and mental health of students and academic staff. Cureus, 12(4), 1-6. https://doi.org/10.7759/cureus.7541

41. Santos, J., Figueiredo, A. S., \& Vieira, M. (2019). Innovative pedagogical practices in higher education: An $\begin{array}{lllll}\text { integrative literature } \quad \text { review. } & \text { Nurse } 17 .\end{array}$ https://doi.org/https://doi.org/10.1016/j.nedt.2018.10.003

42. Schrager, A. (2020). COVID-19 will reshape how we think about higher education and online learning. City Journal: Education, Technology and Innovation. https://www.city-journal.org/post-pandemic-higher-education

43. Sheard, J., \& Markham, S. (2005). Web-based learning environments: developing a framework for evaluation. Assessment Evaluation in Higher 353-368. https://doi.org/https://doi.org/10.1080/02602930500099169

44. Silva, M., \& Cartwright, G. F. (2017). The Internet as a medium for education and educational research. Education Libraries, 17(2), 7-12. https://doi.org/http://dx.doi.org/10.26443/el.v17i2.44

45. Siripongdee, K., Pimdee, P., \& Tuntiwongwanich, S. (2020). A blended learning model with IoT-based technology: effectively used when the COVID-19 pandemic? Journal for the Education of Gifted Young Scientists, 8(2), 905-917. https://doi.org/https://doi.org/10.17478/jegys.698869

46. Soffer, T., \& Nachmias, R. (2018). Effectiveness of learning in online academic courses compared with face-to-face courses in higher education. Journal of Computer Assisted Learning, 34(5), 534-543. https://doi.org/https://doi.org/10.1111/jcal.12258

47. St Phard Jr, J. (2015). Distance education through the lens of USDLA members: A white paper. In M. Simonson, C. Schlosser, \& J. G. Flores (Eds.), Distance Learning Issue (Vol. 12, pp. 15-21). Information Age Publishing.

48. Sun, P.-C., Tsai, R. J., Finger, G., Chen, Y.-Y., \& Yeh, D. (2008). What drives a successful e-Learning? An empirical investigation of the critical factors influencing learner satisfaction. Computers Education, 50(4), 1183-1202. https://doi.org/https://doi.org/10.1016/j.compedu.2006.11.007

49. Tamim, R. M. (2018). Blended learning for learner empowerment: Voices from the middle east. Journal of $\begin{array}{cccccc}\text { Research on } & \text { Technology } & \text { Education, } & 50(1), & 70.83 .\end{array}$ https://doi.org/https://doi.org/10.1080/15391523.2017.1405757

50. van Rooij, S. W., \& Zirkle, K. (2016). Balancing pedagogy, student readiness and accessibility: A case study in collaborative online course development. The Internet Higher Education, 28, 1-7. https://doi.org/https://doi.org/10.1016/j.iheduc.2015.08.001

51. Wang, C., Cheng, Z., Yue, X.-G., \& McAleer, M. (2020). Risk management of COVID-19 by universities in China. Risk and Financial Management, 13(2), 36. https://doi.org/https://doi.org/10.3390/jrfm13020036

52. Zhang, D., \& Zhou, L. (2003). Enhancing e-learning with interactive multimedia. Information Resources Management Journal, 16(4), 1-14. https://doi.org/10.4018/irmj.2003100101 